\title{
SOME CONSIDERATIONS REGARDING THE QUALITY OF PARTY IN INDIVIDUAL LABOUR DISPUTES
}

\section{Lavinia Onica Chipea}

\section{Onica Chipea}

Faculty of Law, Department of Law and Administrative Sciences

University of Oradea, Oradea, Romania

*Correspondence: Lavinia Onica Chipea, University of Oradea, 26 General Magheru St., Oradea, Romania

E-mail: laviniachipea@gamil.com

\section{Abstract}

The paper proposes, based on the analysis of the Code of Civil Procedure and of labor legislation, particularly those of the Labor Code and the Law on social dialogue, to nominate, to develop analytically and synthetically the institution of the quality of party in a individual labour conflict.

Along with the cited legal provisions, the examples of judicial practice in Bihor County point out the specific of labor jurisdiction in the Romanian legal system, jurisdiction governed by the Code of Civil Procedure, as common law, which is adapted to the special legislation of the spirit of this institution.

Keywords: individual labour disputes, parties, employees, employers, accessory voluntary intervention, call in guarantee.

\section{Introduction}

Individual labor conflicts are defined as labor disputes that have as object the exercise of rights and fulfillment of obligations arising from individual and collective labor contracts or from collective bargaining agreements and relations of civil servants, as well as from laws and other legal acts (article 1 letter.p. of Law 62/2011 of Social Dialogue).

Also individual work conflicts are considered: conflicts in connection with the payment of compensation for damages caused by parties by the failure or improper performance of their obligations under the employment contract or service report (Article 1 letter $p 1$ ( $i$ ) of Law no. 62/2011 of Social Dialogue); conflicts about the nullity of individual employment contracts or clauses (article 1 letter $p 2$ (ii) of Law no. 62/2011 of Social Dialogue ); conflicts in connection with termination of service or clauses thereof (article 1 letter p 3 (iii) of Law no. 62/2011 of Social Dialogue).

Labor jurisdiction is "the settlement activity by certain organs of labor disputes and other demands on labor relations and related reports, including regulations relating to competent authorities to resolve such conflicts and demands, as well as the applicable procedural rules" $"$.

We believe that the specific nature of the judicial process by which individual work conflicts are resolved lies in the quality of party in an individual labor dispute.

\section{Parties in Individual Labor Disputes. Theoretical and Practical Aspects}

The provisions of article 267 of the Labor Code and that of Article 1 letter q. of Law 62/2011 of Social Dialogue nominate analytically individuals or legal persons who may be parties in labor disputes:

\footnotetext{
${ }^{1}$ A. Țiclea, A. Popescu, C. Tufan, M. Țichindelean, O. Ținca, Dreptul muncii, "Rosetti” Publishing, Bucharest, 2004 , p.798.
} 
a. employees and any other person, holder of a right or obligation under the Labor Code, other laws, or collective bargaining contracts (agreements);

b. employers - individuals and / or legal persons, temporary work agencies, users, public authorities / institutions and any other person who is employed;

c. unions and employers

d. other natural or legal persons who have this vocation under special laws and the Code of Civil Procedure

The parties of individual labor disputes (before the amendment by the Law of Social Dialogue, regarding conflicts of rights with collective character) that have as an object the exercise of rights and fulfillment of obligations arising from contracts or collective bargaining agreements are all employer as in the case of individual conflicts work that concern the exercise of rights or performance of obligations arising from individual employment contracts or relationships of civil servants (formerly conflicts of individual rights) and employees of this unit. All employees of a collective unit can be part of such a dispute, including employees of a sub-unit (section, workshop) or employees of a particular profession or trade. ${ }^{2}$ In this context arises the problem of representation of both sides of the work conflict. Thus, the employer is represented by its management bodies (director, general manager, manager, etc.). Employees are represented by unions and in establishments where there are no unions by representatives of their delegates elected for this purpose.

Wage-servants (employees) are part of labor disputes, having, as a rule, standing.

Under the provisions of the Labor Code, the employee is a person who is party to an individual contract of indefinite duration, fixed or working part-time or full-time. While major workers defend their own interests, minor employees once employed may be part of a personal work conflict and can support their own work and interests. But under protection rules contained in the law, they are entitled to be assisted when necessary by their legal guardians. $^{3}$

In the community legislation we find the concept of community worker. For example, Regulation nr.1621/from October the 15th 1968 on the free movement of Community workers, Part I is entitled "Employment and family of worker" and Regulation nr.24347 from July the 27th 1992 amending Regulation Part Two nr.1612/68. Thus, the worker is a person who: exercises effective and genuine activity, under the direction of someone else and receives remuneration. ${ }^{4}$

Also in the literature, reference to seasonal workers, cross-border workers are made when speaking of categories for temporary migrants. ${ }^{5}$

By the provisions of Law nr.62/2011 of Social Dialogue, the notion of salaried employee as part of an individual labor dispute, used by Act nr.168/1999 and the provisions of art.248 of the Labor Code Annotated, was replaced by the notion of employee.

The reason of the legislator was to include as part of a conflict of individual employment civil servants also, who are in service relation to the administrative institution where they are operating. As a result, legal and doctrinal analysis of the position of the employee as party to a work conflict can individually apply in the case of public officials.

Regarding the employer, that employer is a party to the conflict who has (or had) the co-contractor quality, so he was in employment relationship with that person being eventually obliged to him. ${ }^{6}$ Extending the interpretation, based on new legal provisions applicable, may

\footnotetext{
${ }^{2}$ D. Top, Tratat de dreptul muncii, Wolters Kluwer Publishing, Bucharest, 2008, p.544.

${ }^{3}$ Employees aged 15-16 years do not fully exercise their rights, having with a limited capacity of labor law, in the process they will be assisted by parents, or in their absence, by the guardian.

${ }^{4}$ Elena Ana Nechita, Libera circulație a persoanelor în spațiul Uniunii Europene, Agora University Press, Oradea, 2010, pp.89-90.

${ }^{5}$ N. Iancu, Migrația internațională a forței de muncă, Pro Universitaria Publishing House, Bucharest, 2013 , p. 92.

${ }^{6}$ For example, in disputes concerning the calculation of the wages due to teachers, teacher standing is entitled to payment of wages. Passive locus belongs where appropriate, to the school (school, college, university, college),
} 
be part of an individual labor dispute that employer who has (or had) the co-contractor quality, so he was in employment or service relationship with that employee.

The law allows the individual employer and the employer's legal entity to be a party to an individual work conflict to ${ }^{7}$. Part of such conflicts may also be temporary ${ }^{8}$ employment agencies, users ${ }^{9}$, and any other person who has a job held under the Labor Code, such as employers for whose benefit seconded employees operate. ${ }^{10}$

The employer is represented in an individual labor dispute by his management organs, in accordance with the law, the articles of association or the statutes. According to the provisions of letter g 62 of Law 62/2011 of Social Dialogue, employers' organizations, at the request of their members, have the right to attend and represent before the courts at all levels, law enforcement jurisdiction or authority of other institutions, by their elected defenders.

Article 222 of the Labor Code Annotated provides that, upon request of their members, unions can represent them in labor disputes under the law. In exercise of the powers conferred expressly to unions, and under art. 28 of Law no. 62/2011 ${ }^{11}$, they are entitled to take any action provided by law, including litigation made on behalf of their members under a written power of attorney from them. Thus, unlike the old regulation (Article 28 of Law no. $54 / 2003$ union, repealed), the new law text establishes the obligation of the union to act following an express mandate from those concerned, including in the case of individual dismissals. The employee in question "must be consulted about the opportunity to trial the employer and the action cannot be brought or continued by the trade union if the concerned objects or discontinues the proceedings" ${ }^{\prime 2}$. In practice a challenge to article 28 of Law of unions was raised, repealed by Law no. 62/2011 on the grounds that these provisions violate Article 51 par. 2 of the Constitution, which states that legally established organizations have the right to address petitions on behalf of the groups they represent. The Constitutional Court rejected the objection ${ }^{13}$ on the grounds that legal action may be brought by the unions not only in partnership, on behalf of their members but also on individual names. In this respect, the Constitutional Court held that "the fundamental right to petition governed by Article 51 of the Constitution, is reflected in demands, claims, complaints and suggestions about solving personal or group problems that do not assume the way of justice, to which authorities are required to meet the terms and conditions established by law, while courts referral for turning a subjective right, ignored or violated, or for having interest obtainable only by way of justice, it is a matter of access to justice, governed by Article 21 of the Constitution and not of the right to petition".

school board territory, even to the main credit coordinator (mayor). Such capacity does not belong to the local council, which is responsible for calculating the salaries. For details see Gabriela Cristina Fren $\square$ iu, Salarizarea personalului didactic din învă $\square$ ământul preuniversitar/superior, in "Revista Română de Dreptul Muncii" Review no.1/2005, pp.55-57.

${ }^{7}$ Individual employer has no capacity to be sued if the object concerned is carrying the mentioned in his employment terms. This interpretation arises from the provisions of Article 2 of the Law nr.130/1999 on measures to protect employed persons, republished in the Official Gazette of Romania, Part I, no. 190 of 20 March 2007, under which labor certificates of employees of individual employers are kept and supplemented by labor inspectorates.

${ }^{8}$ Temporary employment agency is the company which provides users temporary skilled and/or unskilled who employs and pays a for this purpose.

9 The user is the person that temporary employment agency shall provide temporary personnel and whish employs to fulfill a certain specific and temporary task.

${ }^{10}$ Posting is temporarily change of workplace, because of the employer, to another employee for the execution of works in the interest of the latter, detachment is governed by Art. $42-47$ of the Labor Code.

${ }^{11}$ In accordance with article 28 of Law no. 62/2011 social dialogue unions defend their members' rights, arising from labor law, civil service statutes, collective agreements and individual employment contracts and agreements on relations of civil servants in court, enforcement jurisdiction of other institutions or state authorities, or elected by their defenders.

${ }_{12}$ A. Athanasiu, Luminița Dima, Dreptul muncii. Curs universitar, "All Beck” Publishing House, Bucharest, 2005.

${ }^{13}$ Decision no.175/2004 published in the Official Gazette of Romania no. 440 of 17 may 2004. 
In connection with the mentioned legal provisions, in doctrine ${ }^{14}$ arose whether higher associative forms such as federations, confederations and unions have standing territorial capacity in the formulation of judicial action on behalf of workers' unions that represent them. Solutions of judicial practice were contradictory, some Courts ruling that unions have no higher standing, thus rejecting the action and others have decided otherwise. ${ }^{15}$

I concur with those who support the doctrinal opinion based on relevant arguments that "it is illogical and unnatural that a legal union representation is limited to the union of which he is part, excluding the superior organization which has in its structure also the union". The law uses the phrase unions that includes both the employers unions (art. 3, 4 of the Law of social dialogue) and those resulting from their association (41) and union members units that are federations, confederations or territorial unions and at the same time are also members of higher organizations.

The union is able to make a request for intervention under Article 61 of Civil Procedure Code, ${ }^{16}$ but only in the interest of the employee. As an exception, as in the case of discrimination, Article 22 of Government Ordinance no. 137/2000 on preventing and sanctioning all forms of discrimination confers standing to NGOs, the trade union may, in such a situation, make a request for intervention on his behalf. ${ }^{17}$

As we mentioned, the provisions of the Labor Code stipulate that may be parties in individual labor disputes, any person holding rights or obligations under the Labor Code, other laws, or collective agreements, as well as other individuals who have this vocation under special laws or the Code of Civil Procedure.

According to legal provisions, the representation of employees in individual labor disputes is recognized by law only to trade unions; elected employee representatives can not represent the employees. ${ }^{18}$ However, employee representatives are recognized, as main task, their representation in solving collective labor disputes, as provided by law nr.168/1999 ${ }^{19}$, now repealed, and by the new legislation, Law nr.62/2011 of Social Dialogue.

Thus, the employee's heirs may be parties in an individual work conflict in the following situations ${ }^{20}$ :

- The employer must compensate the deceased employee for pecuniary prejudices which he produced by his negligence (e.g. unpaid wages, holiday pay, etc.) (Article 269 paragraph 1 of the Labor Code);

- In the case of restitution, when the deceased employee received from the employer undue amount of money, received goods which he has not earned and which cannot be returned or if he has been rendered services to which he was not entitled, then he is obliged to pay their fee;

- $\quad$ The employer must be compensated by the deceased employee for damage to property caused by his fault and in connection with his work (Art.270 para.1 of the Labor Code). ${ }^{21}$

${ }^{14}$ A. $\square$ iclea, Tratat de dreptul muncii, $5^{\text {th }}$ edition revised, "Universul Juridic" Publishing House, Bucharest, 2011, p.357.

${ }^{15}$ Gabriela Cristina Fren $\square$ iu, Salarizarea personalului didactic din invatamantul preuniversitar/superior, in "Revista Română de Dreptul Muncii" Review no.1/2005, pp.122-123.

${ }^{16}$ Civil Procedure Code, republished in the Official Gazette of Romania, Part I no. 545 of 03.08.2012, entered into force on 15 February 2013.

${ }^{17}$ I. T. Ştefănescu, I., Tratat de dreptul muncii, Wolters Kluwer Publishing House, Bucharest, 2007, p.875.

${ }^{18}$ The doctrine argues that we should extend the role of employee representatives and the representation of employees in individual and collective conflicts of rights, starting from legal provisions that consider the employees' representatives as an alternative of trade unions, exercising powers only in the absence of trade unions; for details see M. Gheorghe, Căi amiabile de soluționare a conflictelor de muncă, "Universul Juridic" Publishing House, Bucharest, 2010, pp.242-243.

${ }^{19}$ R. Dimitriu, Conflictele de muncă şi soluționarea lor, "Tribuna Economică" Publishing House, Bucharest, 2007, p.51.

${ }^{20} \mathrm{R}$. Florian, The procedure of determining the patrimonial liability within the employment relationship, Agora International Journal of Juridical Sciences, no. 2/2012, pp. 44-53. 
People who are parties in relation to the subject of the individual labor dispute can be part in this conflict if they prove an interest. Participation of a third party in a labor dispute can take, given the specifics of the legal work, just the form of an accessory intervention ${ }^{22}$ when, according to art. 63 of the Code of Civil Procedure, it seeks to support defending the interests of any party in the dispute that is the subject of the case.

Concerning the participation of third parties in individual labor conflicts, Labor Inspectorate is entitled, in accordance with paragraph 2 of Article 23 of the Labor Code, to notify the competent court in order to reduce the effects of non-compete clause.

In practice $^{23}$ it is considered appropriate to introduce in the cases that concern individual labor disputes the Labor Inspectorate in order to facilitate the enforcement of the judgment, which will thus be opposable.

In the category of other persons who may have the status of parties to a labor dispute, the doctrine refers ${ }^{24}$ to a situation in which, according to Article 86, paragraph 6 of Law nr.85/2006 on insolvency proceedings, the liquidator / receiver undoes individual work contracts of employees in the unit. Against the redundancies, employees may sue the liquidator / trustee and the legal dispute will be solved according to the rules of labor jurisdiction.

Also, the person selected for employment who has not acquired the status of employee, because the employer hasn't concluded an individual labor contract, can request the competent court, under Article 19 of the Labor Code, compensation for damages due to the failure of the employer of the duty of disclosure ${ }^{25}$.

Article 92 paragraph 2 of the Code of Civil Procedure provides that "The prosecutor may draw conclusions in any civil proceedings, in any phase of it, if he considers it necessary for defending the rule of law, the rights and freedom of citizens". As a result, prosecutors may participate in solving individual labor conflicts in their capacity as official subject of the civil trial, as well as the judge. ${ }^{26}$ So, the prosecutor is part only in procedural meaning or main part or next part and the judgment cannot be ruled in favor or against him. ${ }^{27}$ Thus, the Prosecutor's role in individual labor disputes is reduced; he can intervene in cases where a party of the conflict is a minor employee. ${ }^{28}$

\section{Conclusions}

The analysis of this topic points out again the specific of labor jurisdiction in the Romanian legal system, jurisdiction governed by the Code of Civil Procedure, as common law, which are adapted to the "spirit of labor law".

\footnotetext{
${ }^{21}$ The amendment to the Law no. 40/2011 Article 270 of the Labour Code allows parties to agree on the recovery of employee of prejudice and court intervention is necessary only if there is an agreement of the parties to recover damages.

${ }^{22}$ According to the Civil Procedure Law, the participation of third parties in a process can be achieved by voluntary action, institution that allows a person to intervene in the process to achieve or preserve a right of his; accessory voluntary intervention that allows a person to intervene in support of defending the interests of one of the parties; forced or indirect intervention allows summons to another person, call warranty and appearing the right holder; for details see V. M. Ciobanu, Tratat teoretic şi practic de procedură civilă, Vol I, "National" Publishing House, Bucharest, 1996, pp. 323-327.

${ }^{23}$ It's about the issues raised following a specialist interview guide applied within the territorial labor inspectorate Bihor, June 2010.

${ }^{24}$ A. Athanasiu, M. Volonciu, L. Dima, O. Cazan, Codul muncii. Comentariu pe articole, vol. II, C.H. Beck Publishing House, Bucharest, 2011, p. 413.

${ }^{25}$ A. Athanasiu, Luminița Dima, op.cit., p. 358.

${ }^{26}$ Decision nr. 68/2005.

${ }^{27}$ Gârbaci, C., Cadrul actual al activității procesual-civile a procurorului in "Dreptul” Review, no. 10-11/1994;

${ }^{28}$ M. Gheorghe, op.cit., p. 240.
} 
Law no. 62/2011 of Social Dialogue brought, as we mentioned, significant semantic changes on phrases that define the two parts of the employment relationship. Thus, the text uses the term employer, which is given a broader sense, however, in comparison with the Labor Code, as the employer is "any natural or legal person who may, by law, hire workers based on individual employment contract or service report". In this new understanding, the term employer includes government institutions that are in service relation to officials and employees and who may be parties in individual labor disputes.

\section{Bibliography}

N. Iancu, Migrația internațională a forței de muncă, Pro Universitaria Publishing House, Bucharest, 2013;

R. Florian, The procedure of determining the patrimonial liability within the employment relationship, Agora International Journal of Juridical Sciences, no. 2/2012;

A. Athanasiu, M. Volonciu, L. Dima, O. Cazan, Codul muncii. Comentariu pe articole, vol. II, "C.H. Beck” Publishing House, Bucharest, 2011;

Al. Ticlea, Tratat de dreptul muncii, $5^{\text {th }}$ edition revised, "Universul Juridic" Publishing House, Bucharest, 2011;

Gabriela Cristina Frentiu, Discuții privind dreptul federațiilor, confederațiilor sau uniunilor sindicale de reprezentare a membrilor de sindicat ce constituie federația, confederația sau uniunea sindicală in "Dreptul" Review, no. 4/2011;

Lavinia Onica Chipea, Regimul juridic al conflictelor individuale de muncă, "Universul Juridic" Publishing House, Bucharest, 2011;

Elena Ana Nechita, Libera circulație a persoanelor în spațiul Uniunii Europene, Agora University Press, Oradea, 2010;

I. T. Ştefănescu, Tratat teoretic şi practic de drept al muncii, "Universul Juridic" Publishing House, Bucharest, 2010;

M. Gheorghe, Căi amiabile de soluționare a conflictelor de muncăa, "Universul Juridic" Publishing House, Bucharest, 2010;

L. Uta, F. Rotaru, S. Cristescu, Contractul individual de muncă. Practică judiciară, "Hamangiu" Publishing House, Bucharest, 2009;

D. Top, Tratat de dreptul muncii, Wolters Kluwer Publishing, Bucharest, 2008;

I. Leş, Tratat de drept procesual civil, Fourth Edition, "CH Beck" Publishing House, Bucharest, 2008;

Leontina Constantina Dutescu, Maria Cristina Letu, Unele aspecte privind soluționarea litigiilor având ca obiect nerespectarea clauzei de neconcurență inserată în contractele individuale de muncă in "Revisra Română de Dreptul Muncii" Review, no. $5 / 2008$

I. T. Ştefănescu, Tratat de dreptul muncii, Wolters Kluwer Publishing House, Bucharest, 2007;

R. Dimitriu, Conflictele de muncă şi soluţionarea lor, "Tribuna Economică" Publishing House, Bucharest, 2007;

A. Athanasiu, Luminița Dima, Dreptul muncii. Curs universitar, "All Beck" Publishing House, Bucharest, 2005;

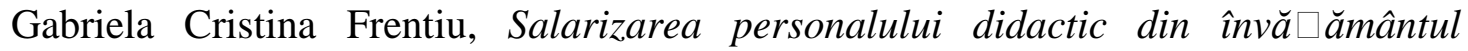
preuniversitar/superior, in "Revista Română de Dreptul Muncii" Review no.1/2005;

A.Țiclea, A. Popescu, C. Tufan, M. Țichindelean, O. Ținca, Dreptul muncii, "Rosetti” Publishing, Bucharest, 2004;

V. Verdinaş, Legea $n r .188 / 1999$ privind Statutul funcționarilor publici, cu modificările ulterioare, republicată, comentată, - $3^{\text {rd }}$ edition, revised and enlarged, "Lumina Lex" Publishing House, Bucharest, 2004;

S. Ghimpu, A. T,iclea, Dreptul muncii, $2^{\text {nd }}$ Edition, "All Beck" Publishing House, Bucharest, 2001; 
SOME CONSIDERATIONS REGARDING THE QUALITY OF PARTY IN INDIVIDUAL LABOUR DISPUTES

D. Firoiu, Dreptul muncii şi securităţii sociale, "Junimea" Publishing House, Bucharest, 1996;

V. M. Ciobanu, Tratat teoretic şi practic de procedură civilă, vol. I, "Național" Publishing House, Bucharest, 1996;

Gârbaci, C., Cadrul actual al activității procesual-civile a procurorului in "Dreptul" Review, no. 10-11/1994. 